\title{
POSTOPERATIVE RETROSPECTIVE ANALYSIS OF THE TREATMENT OF DUPLICATED THUMB
}

\section{ANÁLISE RETROSPECTIVA PÓS-OPERATÓRIA DO TRATAMENTO DAS DUPLICAÇÕES DE POLEGAR}

\author{
Hugo Alberto Nakamoto ${ }^{1,2}$, Frederico Faleiro Ramos ${ }^{2}$, Reinaldo Borges Gonçalves ${ }^{2}$, Dov Charles Goldenberg ${ }^{1,3}$, \\ ROLF GEMPERL ${ }^{3}$ \\ 1. Hospital Menino Jesus, São Paulo, SP, Brazil. \\ 2. Institute of Orthopedics and Traumatology, Hospital das Clinicas (HCFMUSP), Faculdade de Medicina, Universidade de São Paulo, São Paulo, SP, Brazil. \\ 3. Plastic Surgery Division, Hospital das Clinicas (HCFMUSP), Faculdade de Medicina, Universidade de São Paulo, São Paulo, SP, Brazil.
}

\section{ABSTRACT}

Objective: To evaluate postoperative epidemiological and functional factors in patients operated to treat duplicate thumb. Methods: This retrospective case series evaluated 20 patients (23 thumbs) treated from January 2012 to December 2016 at our service. Epidemiological and clinical factors were studied, including Tada score. Results: Of the 34 children who were treated surgically, only 20 appeared for the functional evaluation and were included in the study. Of the operated cases, 60\% were Wassel type 4. All evaluated cases had good functional results (Tada score $\geq 5$, mean score: 6.65$)$. The most frequently used surgical technique was resection of the radial thumb with reconstruction of the radial collateral ligament (47.8\% of cases). Conclusion: Surgical correction of duplicated thumb yields good results, as long as attention is paid to abnormalities in bones, ligaments, and tendons. Level of Evidence IV; Case series.

Keywords: Thumb/abnormalities. Thumb/pathology. Thumb/physiopathology. Thumb/surgery. Classification. Follow-up studies.

\section{RESUMO}

Objetivo: Avaliar os fatores epidemiológicos e funcionais pós operatórios dos pacientes operados por duplicação de polegar. Métodos: Essa é uma série retrospectiva de casos em que foram avaliados 20 pacientes (23 polegares), operados entre janeiro de 2012 e dezembro de 2016, no Hospital Menino Jesus/ SP. Foram estudados fatores epidemiológicos e clínicos, dentre os quais o score funcional de Tada. Resultados: Das 34 crianças operadas, apenas 20 compareceram para avaliação funcional. Dos casos operados, 60\% eram Wassel tipo 4. Todos os casos avaliados obtiveram resultado funcional bom (Tada maior ou igual a 5), com score médio de 6,65. A técnica cirúrgica mais utilizada foi a ressecção do polegar radial com reconstrução do ligamento colateral radial, presente em 47,8\% das vezes. Conclusão: A correção cirúrgica da duplicação de polegar cursa com bons resultados, desde que se atente para as anormalidades osteoligamentares e tendíneas. Nível de Evidência IV; Série de casos.

Descritores: Polegar/anormalidades. Polegar/patologia. Polegar/ fisiopatologia. Polegar/cirurgia. Classificação. Seguimentos.

Citation: Nakamoto HA, Ramos FF, Gonçalves RB, Goldenberg DC, Gemperli R. Postoperative retrospective analysis of the treatment of duplicated thumb. Acta Ortop Bras. [online]. 2018;26(3):158-61. Available from URL: http://www.scielo.br/aob.

\section{INTRODUCTION}

Thumb duplication is a common complex deformity ${ }^{1}$ more frequent in American and Asian populations. Its occurrence is sporadic ${ }^{2}$ with an incidence of 8 per 100,000 live births. ${ }^{3}$

Wassel's classification divides thumb duplications in seven types based on radiologic assessment. ${ }^{4}$ However thumb duplications are not restricted to skeletal alterations. They are frequently associated with deficiency of the collateral ligament and tendon abnormalities. Besides systematizing polydactyly, Wassel's classification might guide treatment, which is usually surgical. The objective of surgery is to obtain a thumb with good mobility, adequate size and growth, minimal scarring and nail deformity, and stable interphalangeal and metacarpophalangeal joints..$^{5,6}$
Tada scoring system was developed with the objective of systematizing functional evaluation of thumb duplication. (Table 1) It is a ranked scale, which assesses four basic areas: range of movement, instability, axial deviation and aesthetic perception. Scores higher than five characterize good results, between 3-4 moderate ones, while those under two indicate poor results.

This study aims at assessing postoperative epidemiological and functional factors in patients operated on for thumb duplication.

\section{MATERIALS AND METHODS}

This is a retrospective study based on a series of cases. After approval by the ethics committee at Hospital Menino Jesus, São Paulo (CAAE: 62431416.5.0000.5639), patients operated on for

All authors declare no potential conflict of interest related to this article. 
Table 1. Tada score.

\begin{tabular}{c|c|c|c}
\hline Postoperative evaluation & & & \\
\hline Score & 2 & 1 & 0 \\
\hline Range of movement $^{\star}(\mathrm{IP}+\mathrm{MCP})$ & $>70 \%$ & $50-70 \%$ & $<50 \%$ \\
\hline Instability & -- & Negative & Positive \\
\hline Axial Deviation & $<10^{\circ}$ & $10-20^{\circ}$ & $>20^{\circ}$ \\
\hline Esthetic & Acceptable & Little deformed & Very deformed \\
\hline
\end{tabular}

Evaluation: >5 good; 3-4 fair; <2 poor. * Interphalangeal + metacarpophalangeal: value stands for the percentage of range of thumb contra-lateral normal movement.

thumb duplication in that hospital between January 2012 and May 2016 were invited to an appointment for functional assessment. All parents/guardians were properly informed on the objectives of the study and they signed the informed consent and permission forms. Medical records were reviewed in order to inform on surgical technique employed and anatomical details of each patient. Clinical-surgical photographic and radiographic records of the patients were also examined.

Epidemiological and surgical aspects were assessed. Epidemiological factors analyzed were age at surgery, follow-up period, sex, laterality and pathological background. Clinical factors observed were Wassel's classification, surgical technique employed, Tada score, early and late complications. Dehiscence or wound infection was considered an early complication, while the perception of hypertrophic scar or pulp hypoplasia was considered a late complication.

Thirty-four children were operated on in the period. Only twenty attended the functional assessment, a total of 23 thumbs. All patients were operated by the same surgeon and underwent the same rehabilitation protocol.

\section{RESULTS}

In the period between January 2012 and May 2017, 34 children were operated on for thumb duplication at Hospital Menino Jesus, however only 20 attended the functional assessment, resulting in a $58 \%$ attendance to the call.

Among the 20 patients assessed, nine are males (45\%) and 11 females (55\%)

Twenty-three hands were studied, 11 of those were right hands (47\%), nine left ones (39\%) and three cases were bilateral (13\%). Among the three bilateral ones, two were male and both displayed the same classification on both hands (Wassel type 4)

The mean age of the children at the time of surgery was 19 months (range: three to 82 months). The mean follow-up period was 26 months (range: nine to 51 months).

Population distribution according to Wassel's classification is demonstrated in Table 2. Type 4 (Figure 1) is the most frequent deformity affecting 14 thumbs, which corresponds to $60 \%$ of the operated thumbs.

None of the patients interviewed has reported comorbidities prior to surgery neither has any of them presented postoperative complications. Functional assessment according to Tada score is presented in Table 3. All patients have scored equal or above five, which means a good functional result. The most frequent score was seven (9/23 thumbs) (43\%). Mean score was 6.5 (range: five to eight).

Surgical procedures consisted of resection of the radial thumb with reinsertion of the collateral radial ligament $(C R L)$; resection of the radial thumb with reinsertion of $C R L$ associated with metacarpal osteotomy and skin graft; and, Bilhaut-Cloquet procedure. The most used technique was the first, being observed in $47.8 \%$ of cases. Distribution of techniques is detailed in Table 4.
Table 2. Distribution of patients according to Wassel's classification.

\begin{tabular}{c|c|c}
\hline & Absolute frequency (\%) & Relative frequency (\%) \\
\hline Wassel & & 0 \\
\hline I & 0 & 17.5 \\
\hline II & 4 & 0 \\
\hline IV & 0 & 60 \\
\hline $\mathrm{V}$ & 14 & 9 \\
\hline $\mathrm{VI}$ & 2 & 4.5 \\
\hline $\mathrm{VII}$ & 1 & 9 \\
\hline Total & 2 & 100 \\
\hline
\end{tabular}

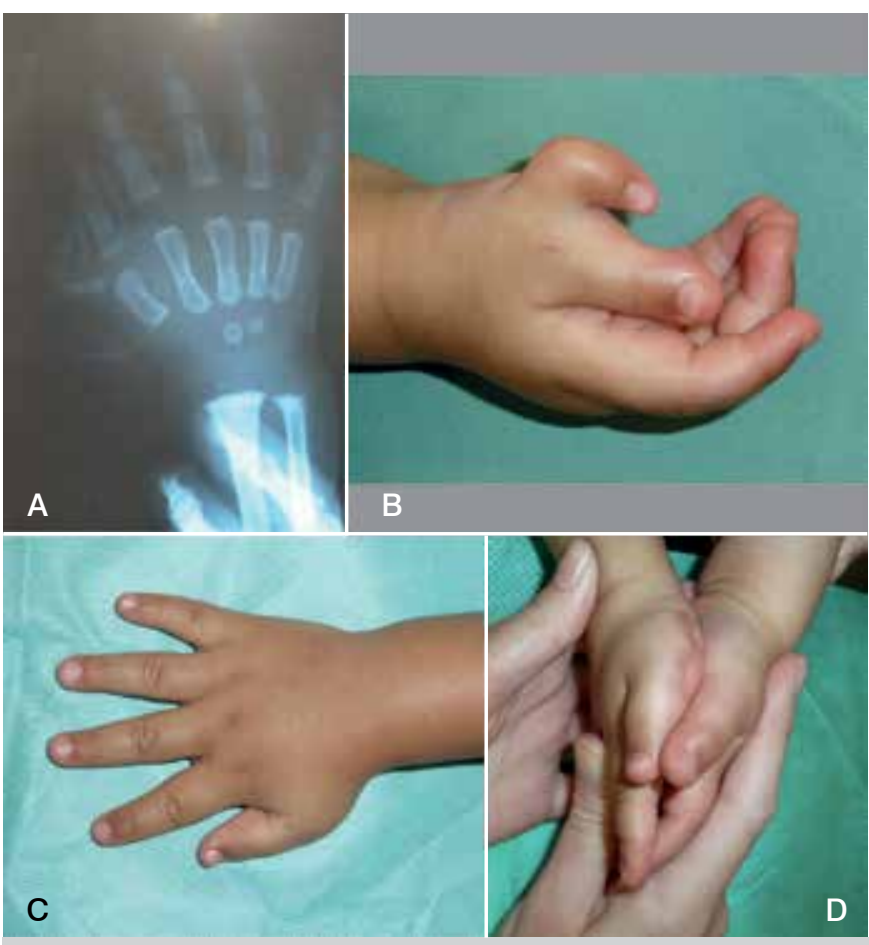

Figure 1. Clinical photograph of Bilhaut-Cloquet procedure. (A) Clinical aspect and preoperative planning of modified Bilhaut-Cloquet procedure. (B) Preoperative radiographic image. (C) Intra-operative image. (D) Late clinical result.

Table 3. Distribution of patients according to TADA score.

\begin{tabular}{c|c|c}
\hline & Absolute frequency (\%) & Relative frequency (\%) \\
\hline Tada & & \\
\hline 5 & 2 & 8.6 \\
\hline 6 & 8 & 34.7 \\
\hline 7 & 9 & 39 \\
\hline 8 & 5 & 17.7 \\
\hline Total & 23 & 100 \\
\hline
\end{tabular}

Table 4. Frequency of surgical techniques used.

\begin{tabular}{c|c|c}
\hline & Absolute frequency & $\begin{array}{c}\text { Relative frequency } \\
(\mathbf{1 0 0 \% )}\end{array}$ \\
\hline Technique & 11 & 48 \\
\hline $\begin{array}{c}\text { Resection of the radial thumb } \\
\text { with reinsertion of CRL }\end{array}$ & 11 & 48 \\
\hline $\begin{array}{c}\text { Resection of the radial thumb with } \\
\text { reinsertion of CRL associated with } \\
\text { osteotomy of metacarpal head }\end{array}$ & 1 & 4 \\
\hline Bilhaut-Cloquet & 23 & 100 \\
\hline Total & \multicolumn{2}{c}{}
\end{tabular}

CRL: collateral radial ligament. 


\section{DISCUSSION}

Thumb duplication is included in Swanson's/International Federation of Societies for Surgery of the Hand (IFSSH) classification as a "duplication" and as a malformation/differentiation affecting the radial-ulnar axis of the hand plate within Oberg-Manske-Tonkin (OMT) classification.

Classic etiological theory for thumb duplication is rupture of the ectoderm and necrosis of the preaxial mesoderm during the embryologic period before the eighth week after fertilization. ${ }^{7}$ Recent studies have shown the importance of programmed cell death in the formation of the thumb and in the formation of the anteroposterior axis of the limb. The Zone of Polarizing Activity (ZPA) is an area of mesenchyme that contains signs, which guide the development of limb bud development. The sonic hedgehog protein expressed in ZPA is related to the radio-ulnar differentiation. Abnormal expression of this protein and other genes such as Hox genes, bone morphogenic protein and GLI3 gene are also involved in thumb duplication. ${ }^{8,9}$ Reaching good functional and esthetic results is fundamental in the treatment of thumb duplication. Thus, guidelines must be followed in order to achieve the best and most predictable possible results. Wassel's classification works as a guide in standardizing procedures of surgical treatment for thumb duplication. Classical treatment consists of resection of the hypoplastic thumb with the preservation of structures in order to reconstruct the remaining thumb..$^{10,11}$

There is greater risk of postoperative thumb instability in type 2 duplication. Once the deformity is articular, collateral ligaments, capsule and tendons need to be preserved and adequately reinserted in thumb reconstruction. There are three cases of type 2 duplication in the series of cases discussed here. Resection of the hypoplastic thumb was the technique employed to operate on two of them because they were asymmetrically bifid. Modified Bilhaut-Cloquet procedure was used on the third patient. ${ }^{12}$ Following this procedure, the surgeon performs an oblique osteotomy on the distal phalange in order to combine the nail bed of the ulnar thumb with the radial osteoarticular structures of the radial thumb. (Figure 2) Good functional and articular results were obtained for the three patients (mean Tada score of 6.3).

There was no thumb duplication type 3 among the cases studied. This type of duplication is treated with resection of the hypoplastic thumb and it presents good prognostic once it does not involve articulating elements.

Type 4 duplication presents higher risk of stiffness and instability. ${ }^{13}$ A larger metacarpal head might cause this, requiring the surgeon to perform an osteotomy in order to create better correspondence between the base of the proximal phalange and the metacarpal head. ${ }^{14,15}$ There are 14 type 4 duplicated thumbs in the sample studied here. Resection of the hypoplastic thumb with reinsertion of the collateral ligament was performed on nine thumbs (64\%), and the osteotomy of the metacarpal head was associated in seven cases (36\%). In all cases, good functional results were obtained (mean Tada score of 6.7). Duplication type 5, as well as type 3, does not involve articulating elements in its reconstruction, hence, there is lower risk of instability. However, unlike in type 3, in type 5 all thenar muscles are inserted into the hypoplastic thumb to be resected. The reinsertion of those muscles in the remaining thumb is a surgical phase to be added in the reconstruction of such cases in order to improve functional results.

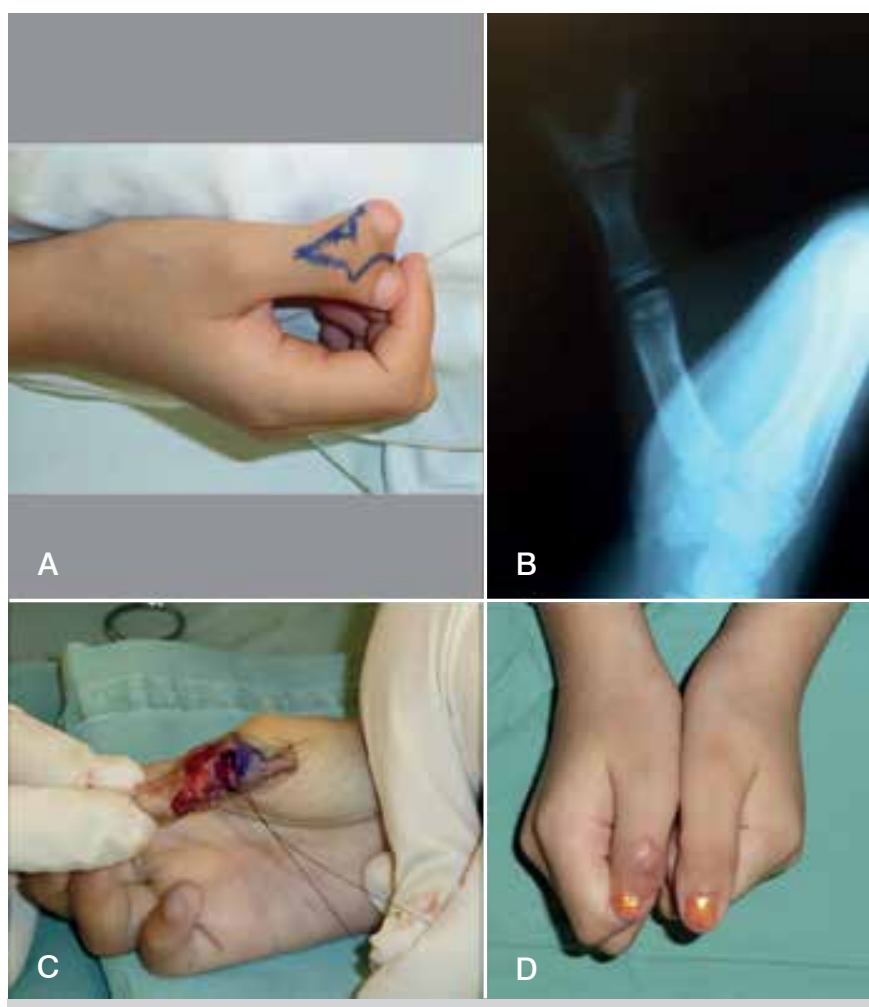

Figure 2. Clinical photograph of Bilhaut-Cloquet procedure. (A) Clinical aspect and preoperative planning of modified Bilhaut-Cloquet procedure. (B) Preoperative radiographic image. (C) Intra-operative image. (D) Late clinical result.

Wasel's type 6 consists of duplication up to metacarpal level. The preservation of articulating structures of the hypoplastic thumb must be combined with the reinsertion of thenar muscles in the reconstruction. ${ }^{16,17}$ There was only one such case in this study and it resulted in a good clinical result.

Treatment of type 7 duplication follows the same principles of the previous ones. Despite its greater anatomical complexity, functional and esthetic outcomes are similar to the other types.

Wassel's classification is extremely important in evaluating and guiding the treatment of thumb duplication. However, this classification presents the limitation of considering only the radiographic component of the duplication. Intra-operative findings are varied and might include from cartilage fusion not visible in radiographic images (which changes the type of duplication within Weasel's classification), to tendon abnormalities, enlarged articular surfaces and capsule-ligament laxity. ${ }^{18}$ These morphological alterations should be considered in surgical reconstruction of thumb duplication and they are directly involved in the success of the treatment. ${ }^{19}$

\section{CONCLUSION}

Surgical reconstruction of thumb duplication presents good esthetic and functional results, since bone and soft tissues morphologic abnormalities are adequately approached. Wassel's classification is useful as a guide in choosing the surgical technique thus providing patients and parents with satisfactory results.

AUTHORS' CONTRIBUTIONS: Each author made significant individual contributions to this manuscript. RBG (0000-0002-1596-5353) * performed the surgeries and wrote and reviewed the article; FFR (0000-0002-0784-0921)*: analyzed the data and conducted the statistical analysis; HAN (0000-00027301-4329 * : performed the surgeries and contributed to the concept and design of the article; DCG (0000-0001-5953-2448)*: provided institutional and intellectual support; RG (0000-0001-9913-6079)*: provided technical advice during the surgeries and the development of the manuscript. All authors approved the final version of this manuscript. *ORCID (Open Researcher and Contributor ID). 


\section{REFERENCES}

1. Naasan A, Page RE. Duplication of the thumb. A 20-year retrospective review. J Hand Surg Br. 1994;19(3):355-60.

2. Yen $\mathrm{CH}$, Chan $\mathrm{WL}$, Leung $\mathrm{HB}$, Mak KH. Thumb polydactyly: clinical outcome after reconstruction. J Orthop Surg (Hong Kong). 2006;14(3):295-302.

3. Ezaki M. Radial polydactyly. Hand Clin. 1990;6(4):577-88.

4. Andrew JG, Sykes PJ. Duplicate thumbs: a survey of results in twenty patients. J Hand Surg Br. 1988;13(1):50-3.

5. Goldfarb CA, Patterson JM, Maender A, Manske PR. Thumb size and appearance following reconstruction of radial polydactyly. J Hand Surg Am. 2008;33(8): 1348-53.

6. Tonkin MA. Thumb duplication: concepts and techniques. Clin Orthop Surg. 2012;4(1):1-17.

7. Song KM. Thumb duplication. In: Song KM, editor. Orthopaedic knowledge update: pediatrics 4. $4^{\text {th }}$ ed. New York: American Academy of Orthopaedic Surgeons; 2011. p. 134-51.

8. Tonkin MA, Bulstrode NW. The Bilhaut-Cloquet procedure for Wassel types III, IV and VII thumb duplication. J Hand Surg Eur Vol. 2007;32(6):684-93.

9. González MC, López LMP, Soto GM, Iglesia DG. Prognostic value of age and Wassel classification in the reconstruction of thumb duplication. J Child Orthop. 2013;7(6):551-7.

10. Dautel G, Perrin P. Use of an Axial Flap to Increase the Girth of Wassel IV Thumb Reconstructions. J Hand Surg Am. 2015;40(7):1327-32.

11. Townsend DJ, Lipp EB Jr, Chun K, Reinker K, Tuch B. Thumb duplication,
66 years' experience--a review of surgical complications. J Hand Surg Am. 1994;19(6):973-6.

12. Baek GH, Gong HS, Chung MS, Oh JH, Lee YH, Lee SK. Modified Bilhaut-Cloquet procedure for Wassel type-II and III polydactyly of the thumb. Surgical technique. J Bone Joint Surg Am. 2008;90 Suppl 2 Pt 1:74-86.

13. Goffin D, Gilbert A, Leclercq C. Thumb duplication: surgical treatment and analysis of sequels. Ann Chir Main Memb Super. 1990;9(2):119-28.

14. Horii E, Nakamura R, Sakuma M, Miura T. Duplicated thumb bifurcation at the metacarpophalangeal joint level: factors affecting surgical outcome. J Hand Surg Am. 1997;22(4):671-9.

15. Maillet M, Fron D, Martinot-Duquennoy V, Herbaux B. Results after surgical treatment of thumb duplication: a retrospective review of 33 thumbs. J Child Orthop. 2007;1(2):135-41.

16. Patel AU, Tonkin MA, Smith BJ, Alshehri AH, Lawson RD. Factors affecting surgical results of Wassel type IV thumb duplications. J Hand Surg Eur Vol. 2014;39(9):934-43.

17. Tien YC, Chih TT, Wang TL, Fu YC, Chen JC. Soft tissue reconstruction for type IV-D duplicated thumb: a new surgical technique. J Pediatr Orthop. 2007;27(4):462-6.

18. He B, Nan G. Causes of secondary deformity after surgery to correct Wassel type IV-D thumb duplication. J Hand Surg Eur Vol. 2016;41(7):739-44.

19. Larsen M, Nicolai JP. Long-term follow-up of surgical treatment for thumb duplication. J Hand Surg Br. 2005;30(3):276-81. 